\title{
Provision of Peace and Right to Health through Sanctions: Threats and Opportunities
}

\author{
Reihaneh Dastafkan, PhD ${ }^{1}$; Hadi Salehi, $\mathrm{PhD}^{2 *}$; Mohammad Mehdi Hooshmand, $\mathrm{MA}^{3}$ \\ ${ }^{1}$ International Law Department, School of Law, Shahid Beheshti University, Tehran, Iran \\ ${ }^{2}$ Assistant Professor, Public Law Department School of Law \& Political Science, Shiraz University, Shiraz, Iran \\ ${ }^{3}$ International Law Department, School of Law \& Political Science, Shiraz University, Shiraz, Iran
}

\begin{abstract}
According to the purposes for the formation of the United Nations, sophistication of institutions like the Security Council must be evaluated based on the provision of peace and how they guarantee human rights. Therefore, in case Security Council does not follow these two mentioned factors, its function would be itself a threat to the international peace and security. This analytical research is based on collecting library theoretical data related to different field studies which investigated the effects of sanctions issued by the Security Council, the United States and the European Union on citizens' health and tried to assess both their efficiency and legitimacy. The right to health is connected with the right of living. In case enough drugs, appropriate treatment and medical equipment are not provided at the proper time, both physical and mental health might be threatened and this can cause death of a large number of people. Considering the Security Council as an institution which is expected to take into account the citizens' basic rights and not to ignore its own initial objective, the present paper was an attempt to provide explanations for the above concepts and their relationships and to analyze the findings of previous field studies. The paper concluded that sanctions issued by the Security Council and the United States are potentially functioning as threats to the international peace and so these sanctions are violating the citizens' right to health.

Keywords: Economic sanction, Jurisprudence, International law, International peace, Legal obligation, Right to health, Smart sanction

Cite this article as: Dastafkan R, Salehi H, Hooshmand MM. Provision of peace and right to health through sanctions: threats and opportunities. Arch Iran Med. 2020;23(4 suppl 1):43-48. doi: 10.34172/aim.2020.s9.
\end{abstract}

Received: May 12, 2019, Accepted: October 12, 2019, ePublished: April 1, 2020

\section{Introduction}

The theory of 'smart sanction' was proposed as a result of criticisms imposed on human rights regarding the direct effect of economic sanctions on citizens' lives and consequently, violation of human rights for the people of a nation. The aim was to mitigate the negative effects of these sanctions on citizens, which are common people and, instead, point at specific groups at the higher politicalofficial levels. In addition to considering the legitimacy of sanctions, including smart and non-smart sanctions, according to the international legal system (which is beyond the scope of the present paper), it is necessary to examine the validity of the claims made by the theorists of smart sanctions to check if they comply with human rights. This is because if the apparently 'smart' sanctions impose threats on the right to health, availability of drugs, medical equipment and effective treatments, macro-variables such as public development and the citizens' welfare, obvious violation of human rights can be seen; this is because as these theorists themselves have acknowledged, such sanctions can have qualitatively widespread and quantitatively large effects such as significant rise in death rate (particularly in vulnerable groups like women, children, elderlies and people with special diseases).

Therefore, reviewing cases of sanctions imposed against a number of countries such as Iraq, Cuba, Haiti and Iran, this paper questions if harmful consequences of these sanctions have surpassed their inhibiting effects. Also, it investigates if availability of important drugs and death rate in vulnerable groups have undergone changes in comparison with the time of the start of sanctions. Another point is whether or not devising these new sanctions violates the citizens' human rights.

In doing so, it is necessary to analyze the legal fundamentals of the Security Council in devising these sanctions in an a priori critical study in light of restoration of direct effects on right to the common citizens' health. These fundamentals are legally analyzed in form of $a$ posteriori conclusive study so that a number of practical strategies would be suggested in line with a human right pattern to guarantee the citizens' right to health.

In addition, the present authors adopted a descriptive/ analytical method by conducting library studies to mitigate the damaging effects of economic sanctions issued by the Security Council and other authorities in charge of this. The aim would be to help the citizens and statesmen, and 
to optimally manage the resources and then to recommend practical strategies.

\section{Preliminaries and Legal Fundamentals}

The term 'sanction' refers to a systematic reluctance to hold social, economic, political and military actions of a state or of a specific group of states to penalize another state or the sanctioned entity or to force them to accept the intended behavior ${ }^{1}$; economic sanctions are more common than the other types. Although there are some instances of penalty in any sanction, they are merely devised with the aim of penalizing the sanctioned country; instead, the aim of sanctions is to create changes in the political behaviors of that country. ${ }^{2}$ A number of researchers hold that the most important function of any sanction is that they are inhibiting. ${ }^{3}$

Sanctions can be classified into 'primary' and 'secondary' sanctions. If sanctions are merely related to relations of two countries, they are primary, i.e. with a limited range. While if one country expands the range of its sanctions and bans its economic, financial and other relations with countries which are in relation with the sanctioned country, the case of secondary sanctions can be seen.

Although sanctions are followed by economic expenses which would color the benefits of internal trade, such expenses are negligible as compared to interruptions made as a result of military expenses. Sanctions mostly impose expenses on the sanctioned country, but most of these sanctions address the citizens rather than the socalled regime. Sanctions usually happen exclusively by the markets of the developed country against the more dependent weaker state.

Article 41 of the United Nations Charter allows only those actions of total or partial stopping of relations when international peace is threatened. This is because the Security Council is expected to 'improve international law and support legal laws of the states'. In addition, in case there is a controversy between the Security Council Resolution and the United Nations Charter, the charter serves as the reference as the superior law. In the Namibian case, the ICJ stated that the Security Council's powers are not unlimited; on the contrary, it is bound to comply with the fundamental principles and the objectives that have been mentioned in chapter 1 of the Charter.

Nowadays, an increasing consensus of human rights is being formed ${ }^{4}$ which legitimizes only imposition of a certain limited types of sanctions, to be referred to as the final choice of the United Nations Charter. According to the introduction and clause 3 of article 1 of the charter, 'to achieve international cooperation in solving international problems of an economic character' is an international objective. Due to the notion that 'internal peace' is achieved with cooperation in the economic affairs and due to the obligation of the Security Council to respect human rights and the international law, in general, and the United
Nations Charter, in particular, actions of the Security Council in imposing comprehensive sanctions can be essentially considered as a violation of the United Nations Charter and threatening of the international peace.

Whenever governments have deep economic relations with each other, they do not allow the violation of one another's rights and interests. Targeting individuals and a limited number of institutions, smart sanctions reduce the effects of comprehensive sanctions on economic and commercial relations of governments, ${ }^{4}$ though changes in the method of imposing sanctions from addressing governments to targeting real and legal persons caused new problems. New sanctions mostly deal with the violation of rights of those individuals who have made some decisions within the official hierarchy, with no legal responsibility; additionally, smart sanctions suffer from lack of function in comparison with comprehensive sanctions.

\section{Effects of Sanctions on the Right of Hygiene and} Healthcare (Some Cases from the Past)

Right to health and hygiene was initially defined in the WHO constitution. The Constitution was adopted by the International Health Conference held in New York from 19 June to 22 July 1946, signed on 22 July 1946 by the representatives of 61 states, entered into force on 7 April 1948. Amendments adopted by the 26th, 29th, 39th and 51st World Health Assemblies (resolutions WHA26.37, WHA29.38, WHA39.6 and WHA51.23) came into force on 3 February 1977, 20 January 1984, 11 July 1994 and 15 September 2005. In the introduction to this constitution, it is stated that "health does not only mean complete physical, mental and social health or mere lack of a disease or disability". ${ }^{5}$ In addition, in this introduction, it has been mentioned that "having the highest standards of health, disregard of race, religion, political stance or social conditions is basic human right" ${ }^{6}$ Moreover, right to health and hygiene was known as a basic human right in article 12 of Covenant on Economic, Social and Cultural Right. ${ }^{7}$ If principles of rights written in this covenant are considered as parts of the legitimate international rights (and no one could can deny this), then each action of the Security Council which would threaten or limit the right to health and hygiene or its sub-rights such as availability of medicine and optimal treatment can be conceived as obvious violation of the internal law.

The right to health covers a wide range of factors which help people to live healthy lives. The Committee on Economic, Social and Cultural Rights considers these factors to be fundamental components of the right to health: safe drinking water, food safety, appropriate and enough nutrition, healthy work and living conditions, information and education on health and hygiene and gender equality. ${ }^{8}$ Health and hygienic services are related to variables such as safe water, appropriate infrastructures in health, electricity, medical equipment such as ambulance, 
laser, etc. More vulnerable countries are those which depend on imports to a greater extent. In these countries, effects on citizen are increasingly raised due to lack of currency resources for importing the urgent health-related goods and lack of time needed for management of the required resources. ${ }^{9,10}$

As an example, Cuba was geographically, and not politically, isolated. However, despite US sanctions, many countries continued to maintain their economic relations with Cuba. The borders between Haiti and the Dominican Republic helped then to import fuel. However, Iraq did not have any of these chances and, as a result, was more affected. ${ }^{10-12}$

In Iraq, sanctions began with forbidding of all imported goods, except for medicine. They were extended by the Security Council in January and February 1991 after the Gulf War. In April 3, Iraq was allowed to import food beside medicine. From 1991 to 1993, humanitarian organizations could help the import of only 5\% of the urgent medicine and food. This was because those countries which were enemies of Iraq did not dedicate adequate budget to this country. ${ }^{13}$ In August 1991, the Security Council issued the resolution 706, after which selling oil was allowed for importing humanitarian goods. In 1996, Iraq accepted the 'oil for food' program and the first humanitarian package was sent in $1997 .{ }^{14}$

In Cuba, despite the problems in a number of areas, since 1992, the health of infants, children and mothers started to improve. In 1998, infant mortality dropped to 1.7 per 1000 live births. Despite a significant decrease in the amount of calories, the percentage of all the births below $2.5 \mathrm{~kg}$ dropped by $6.7 \%$. During this period, more than $99 \%$ of births occurred in health centers, and fewer than 47 mothers died per 100000 births. ${ }^{10,15,16}$

Two widespread field studies were carried out in 1999, evaluating changes in mortality rates among infants under 5 in Iraq. ${ }^{17-19}$ Both of these studies confirmed that death rate was doubled after 1995 in comparison with the 1980s and that the rate of mortality was smaller in northern compared to southern and central parts. ${ }^{20}$ They concluded that a significant increase was occurring in mortality rates in Iraq. It was indicated that such an increase in the mortality rate was higher than what Iraq government claimed; it was about 300000 in infants and children under $5 .{ }^{17}$

With these points in mind, it is time to question the effects of sanctions on Iran. The Security Council approved its sixth resolution and the fourth resolution against Iran in June 2010. ${ }^{21}$ Before this, the 1803 resolution which was the third resolution against Iran was approved by the Security Council in 2007 and the 1737 resolution was approved after a consensus of the members in 2006. Studying these resolutions, particularly the 1929 resolution, can reveal important points. One of these points is that clauses $6,7,8$ and 9 of the 1929 resolution have covered two-function materials in sanctions regime.
This highly damages the nature of targeted sanctions. Using expressions such as 'ballistic missile technology', 'heavy water related facilities', 'materials related to military and army technology' caused the inclusion of materials in the lists of sanctions, which have uses for both military and nuclear purposes and medicine, pharmacy, hygiene and environment purposes. ${ }^{21}$ Also, petrochemical materials can be cited among these examples. These materials are so highly significant in industry and the related equipment and materials that the Security Council itself has noted the relationship between the materials required in the petrochemistry and nuclear fuel cycles. ${ }^{4}$

It is also necessary to refer to techniques for analyzing and measuring nanometer-level molecular levels using machines such as SEM and TEM, which are widely used in the identification of the accuracy of methods employed in production of materials on molecular scales (nanoscales). ${ }^{22}$ Among the uses of these materials are use in pharmacy industries, where they are used to improve the efficacy and absorption of medicine; also, they are used to reduce the side effects of drugs when they are taken in large amounts. In addition, these equipments are used in the production of various types of heavy metals such as titanium and germanium; these alloys are used for manufacturing equipment in medical and dentistry equipment, ranging from surgical tools to bone plates and implants. ${ }^{3}$ The 1929 resolution has obviously affected the import of these parts and equipment which are related to the petro-chemistry industry. Followed by imposing sanctions on goods and equipment of this industry, a significant damage can be expected on other industries, too. Sanctions on petro-chemistry goods such as povidone iodine, which is an important material in producing betadine, and poly-propylene, which is the main material used to produce the container and caps of drugs, can lead to harmful effects on citizens' healthcare. ${ }^{22}$

Although the 1929 resolution has apparently devised many smart sanctions, considering that a number of equipment and goods are two-functional, it has in fact violated the basic rights of the citizens including the right of life, the right to health, the right of the environment and even the right of free treatment; and this would cause irreparable effects.

Despite these sanctions, healthcare condition has improved after the Islamic Revolution and such improvement is a result of healthcare programs taken by the state. ${ }^{19}$ Rural areas enjoy this healthcare improvement to the same extent as the urban areas. In 2006, life expectancy was 70 for men and 74 for women. In the same year, healthy life expectancy was 60 for men and 62 for women. In 2004, mortality rate was 29 per 1000 for infants, which was almost half of that in 1999, which was 54 per 1000 . Nowadays, morality rate is 24.6 deaths per 100000 for mothers, while it was 91 per 100000 in 1990. In 2007 , morality rate was 18.9 deaths for infants 
and 22 deaths per 1000 for children under 5. Between the years 2000 and 2007, 7\% of the infants suffered from underweight while this rate was $11 \%$ for the children under 5 , with $2 \%$ being in a bad condition. Malnutrition and underweight were more than the average in different parts of the country. In 2008, rate of cancer was 100 in 100000 and this caused $11.86 \%$ of all deaths. ${ }^{23}$

Although it seems that medicine is not included in the list of sanctions, Iranian medical companies need to pay in advance for importation and this is due to limitations on the banking and insurance related transactions. ${ }^{23,24}$ The current situation in Iran regarding medicine is indicative of unfavorable effects of sanctions on common people and public health. This undesirable effect is not only related to the difficulty in buying medicine; it would endanger public health in the long term. On the other hand, with lowering of the country income and the value of the national currency, the ability to buy foreign medicine and raw materials has reduced.

On top of all, the impact of economic sanctions can be human rights violation from a legal point of view. Economic sanctions inevitably cause further retrogression of human rights status. Moreover, extensive sanctions, especially those inflicted multilaterally, assume to cause greater integrity rights abuses than limited sanctions. ${ }^{25}$

Regarding sanction goals, practical results indicate that human rights sanctions are also deleterious, resulting in a greater possibility of infringement of integrity rights. In addition, just like the direct result of sanctions, economic coercion leads to violation of human rights, the longer the sanctions last. ${ }^{25,26}$

This study can have several inferences as far as the study of economic sanctions is concerned. First, it appears that economic sanctions not only often fail to achieve their intended policy goals, but they also lead to unintended negative impacts on human rights. In addition to the evidence presented by earlier case studies, this study attempts to provide a cross-national-empirical evidence confirming the deleterious effects of sanctions on human rights. ${ }^{27}$

Many international legal documents insist on the right to health for all, especially children and other vulnerable people. This special human right includes various rights like medical care, access to medicine and drugs and other qualifications which economic sanctions would inevitably violate. Several prominent international law regulations are referred below:

Article 25 of the United Nations' 1948 Universal Declaration of Human Rights states that "Everyone has the right to a standard of living adequate for the health and well-being of himself and of his family, including food, clothing, housing and medical care and necessary social services."

"The right to public health, medical care, social security and social services" is mentioned in Article 5 of the International Convention on the Elimination of All Forms of Racial Discrimination, which was adopted in 1965 and entered into effect in 1969.

Several important statements are mentioned in Article 12 of the International Covenant on Economic, Social and Cultural Rights; for example:

"The right of everyone to the enjoyment of the highest attainable standard of physical and mental health" or "the creation of conditions which would assure to all medical service and medical attention in the event of sickness."

Health is mentioned on several instances in the Convention on the Rights of the Child (1989). Article 3 calls upon parties to ensure that institutions and facilities for the care of children adhere to health standards. Article 17 recognizes the child's right to access information that is pertinent to his/her physical and mental health and wellbeing. Article 23 makes specific reference to the rights of disabled children, in which it includes health services, rehabilitation and preventive care. Article 24 outlines child health in detail, and states, "Parties recognize the right of the child to the enjoyment of the highest attainable standard of health and to facilities for the treatment of illness and rehabilitation of health."

Table 1 presents a summary of some of the most remarkable literature in the field of economic sanctions and their impacts on human rights.

Table 1. Remarkable Literature review

\begin{tabular}{|c|c|c|c|}
\hline Author & Title & Year & Results \\
\hline Weiss et $\mathrm{a}^{28}$ & Weighing Humanitarian Impulses & 1999 & $\begin{array}{l}\text { Substantial suffering by vulnerable groups in Iraq, former Yugoslavia, and Haiti } \\
\text { has led to a 'bust' for this foreign policy tool. Sanctions can be designed to } \\
\text { be more effective and less inhumane than they are at present, but much more } \\
\text { research is required about their precise impact on civilians and on targeted } \\
\text { regimes. }\end{array}$ \\
\hline Peksen ${ }^{25}$ & $\begin{array}{l}\text { Better or Worse? The Effect of Economic } \\
\text { Sanctions on Human Rights }\end{array}$ & 2009 & $\begin{array}{l}\text { Based on the research findings of this study, it is evident that the use of } \\
\text { 'sticks', at least in the form of economic coercion as a foreign policy tool, } \\
\text { does not contribute to the advancement of human rights. }\end{array}$ \\
\hline Gibbons $^{29}$ & $\begin{array}{l}\text { Sanctions in Haiti: Human Rights and } \\
\text { Democracy Under Assault }\end{array}$ & 1999 & $\begin{array}{l}\text { Sanctions may cause disproportionate stress on ordinary citizens, while } \\
\text { allowing the targeted regimes to avoid the cost of coercion. }\end{array}$ \\
\hline Hufbauer et $\mathrm{a}^{30}$ & $\begin{array}{l}\text { Economic Sanctions, Reconsidered: } \\
\text { History and Current Policy }\end{array}$ & 1990 & Economic sanctions fail frequently in achieving their intended policy goals. \\
\hline Pape $^{27}$ & 'Why economic sanctions do not work' & 1997 & $\begin{array}{l}\text { Sanctions have succeeded in } 5 \text { of } 115 \text { attempts, and thus, there is no sound } \\
\text { basis for even qualified optimism about effects of sanctions. }\end{array}$ \\
\hline
\end{tabular}




\section{Conclusion}

Multilateral and comprehensive economic sanctions in countries which are highly dependent on imports and which are not implemented hesitantly and which are followed by other socio-economic pressures, have the greatest impact on public health. Iraq had all these factors and therefore, the country was particularly vulnerable. Haiti was involved with a number of disturbances occurring among the families both simultaneous with and after the imposition of sanctions. No sanctioned country can compensate for its lost income via humanitarian relief; as a result, the economic, social and political chaos continues for many years after the end of the sanctions and this might deepen the crisis.

Furthermore, it was found in some cases that infant deaths in some sanctioned countries decreased even when there was a shortage of resources. This occurs when rare resources are properly managed and distributed, health officials and national authorities promote child health, and parents are taught to take specific actions in this regard. In Iran, after the imposition of the sanctions, death rate decreased after primary healthcare was offered for women and infants. Even after imposing sanctions, some medicines and medical equipment were produced inside the country.

In sanction conditions, non-governmental organizations need to make close relationships with those authorities who are involved with human rights in order to re-identify the power and resources of the country and its people. Such approaches require creativity and leadership and objectives of economic sanctions also need to be more accurate and clear.

On the other hand, sanctioning authorities are not totally free in devising these sanctions and they need to consider the basics of human rights. A review of the previously sanctioned states shows that economic sanctions have not been able to reach the goals for which they were once devised. In most cases, they caused mere damage on health, welfare, and lives of common people. Therefore, through making sanctions targeted, accurately mentioning sanction-excluded goods, accurately defining twofunctional goods, increasing supervision and development of humanitarian measures and devising national policies for the support of vulnerable groups using reasonable healthcare actions, one can mitigate the humanitarian damages resulting from sanctions, particularly smart sanctions. In this way, loss of lives would not occur and the sanctioned country would be rebuilt more easily in the future.

\section{Authors' Contribution}

$\mathrm{RD}$ designed and analyzed the data and co-wrote the paper. $\mathrm{MMH}$ is scientific editor and co-wrote the paper. HS as corresponding author, co-wrote the paper and supervised the research.

\section{Conflict of Interest Disclosures}

None.

\section{Ethical Statement}

Not applicable.

\section{References}

1. Evans G, Newnham J. The Penguin Dictionary of International Relations. London: Penguin Books; 1998.

2. Hadadi M. International sanctions, tools for national politics or guarantees for the international actions. Portal of Islamic and Human Sciences. 2002;32:9-12.

3. Gostaresh-e Sanat Newspaper. 2017;47:2. Available from: http://www.sanatnewspaper.com/repository/47/2.pdf.

4. Zamani S, Mazaheri J. Sanctions of the Security Council in light of the 1929 resolution: preserving or threatening peace? International Journal of Law. 2011;28(44);115-61.

5. Zarif MJ, Mirzaee S. US Unilateral Sanctions against Iran. Iranian Journal of International Affairs. 1997;9:1-20.

6. Akande D. The International Court of Justice and the Security Council: Is There Room for Judicial Control of Decisions of the Political Organs of the United Nations? Int Comp Law Q. 1997;46(2):309-43.

7. Berggren G, Castle S, Chen L, Fitzgerald W, Michaud C, Simunovic M. Sanctions in Haiti: crisis in humanitarian action. Boston (MA): Harvard School of Public Health, Program on Human Security; 1993.

8. Cheraghali AM. Cost effectiveness of Iran national plasma contract fractionation program. Daru. 2012;20(1):63. doi: 10.1186/2008-2231-20-63.

9. Cheraghali AM. Impacts of international sanctions on Iranian pharmaceutical market. Daru. 2013;21(1):64. doi: 10.1186/2008-2231-21-64.

10. Fitzmaurice SG. Namibia case (dissenting opinion), IC) reports; 1971. Available from: https://www.icj-cij.org/files/ case-related/53/053-19710621-ADV-01-08-EN.pdf.

11. Clawson PA. Oil for food or the end of sanctions. Policy Watch. 1998.

12. Concluding Observations of the Committee on Economic, Social and Cultural Rights.1997: Iraq (E/C.12/1/Add.17). Available from: https://www.refworld.org/docid/3ae6ae5817. html.

13. Concluding Observations of the Committee on the Rights of the Child, 1998; Iraq (CRC/C/15/Add.94). Available from: http://hrlibrary.umn.edu/crc/iraq1998.html.

14. Country Cooperation Strategy for $\mathrm{WHO}$ and the Islamic Republic of Iran. 2010-2014, EM/ARD/038/E. WHO Regional Office for the Eastern Mediterranean; 2011.

15. Fassbender B. Uncertain steps into a post-cold war world: The role and functioning of the UN Security Council after a decade of measures against Iraq. European Journal of International Law. 2002;13(1):273-303.

16. International Covenant on Civil and Political Rights [GA / Res/2200A(XXI)]; 16 December 1966.

17. Garfield R, Santana S. The impact of the economic crisis and the US embargo on health in Cuba. Am J Public Health. 1997;87(1):15-20. doi:10.2105/ajph.87.1.15

18. General Comment No.14 on the right to health. The Committee on Economic, Social and Cultural Rights; 2000.

19. World Health Organization. The health conditions of the population in Iraq since the Gulf crisis. Baghdad: WHO/ EHA/96.1; 1996.

20. Haiti 1995 Nutrition Surveys by Department of Port-auPrince. Haiti: Ministry of Public Health and Population; 1997.

21. Kondoch B. Limits of Economic Sanctions under International Law: The Case of Iraq. Int Peacekeep. 2001;7:267.

22. Ochoa FR, Pardo CM. Economy, politics, and health status in Cuba. Int J Health Serv. 1997;27(4):791-807.doi: 10.2190/ HBXE-6KWM-0H9V-1DCF.

23. UNICEF. Disastrous Situation of Children in Iraq. UNICEF; 4 October 1996. 
24. UNICEF. Child and Maternal Mortality Survey, Preliminary Report. Baghdad, Iraq; 1999.

25. Peksen D. Better or worse? The effect of economic sanctions on human rights. J Peace Res. 2009;46(1):59-77.

26. Lucena Carneiro C, Apolinário L Jr. Targeted Versus conventional economic sanctions: What is at stake for human rights? International Interactions. 2016;42(4):565-89.

27. Pape RA. Why economic sanctions do not work. International
Security. 1997;22(2):90-136.

28. Weiss TG. Sanctions as a Foreign Policy Tool: Weighing Humanitarian Impulses. J Peace Res. 1999;36(5):499-509.

29. Gibbons ED. Sanctions in Haiti: Human Rights and Democracy under Assault. Praeger; 1999.

30. Hufbauer GC, Schott JJ, Elliott KA, Economic Sanctions Reconsidered: History and Current Policy. Peterson Institute; 1990.

(c) () () 2020 The Author(s). This is an open-access article distributed under the terms of the Creative Commons Attribution License (http://creativecommons. org/licenses/by/4.0), which permits unrestricted use, distribution, and reproduction in any medium, provided the original work is properly cited. 